\title{
金沢景観形成地区の居住者の満足度と転居意向のファジィ分析 FUZZY ANALYSIS ON INHABITANTS' SATISFACTION AND INTENTION OF MOVING OUT IN TOWNSCAPE HUSBANDRY DISTRICT OF KANAZAWA
}

\author{
孫 京 廷*, 宗本順三**, 吉田 哲***, 石原清行**** \\ Kyungjung SON, Junzo MUNEMOTO, Tetsu YOSHIDA and Kiyoyuki ISHIHARA
}

\begin{abstract}
The purpose of this paper is to clarify the relation between inhabitants'satisfation and intention of moving out for the present condition of residential environment in townscape husbandry district of Kanazawa. The method of this study is to administer questionnaire with inhabitants in these districts about satisfation and intention of moving out, and to analyze the result using Fuzzy measuring. The findings are as follows. First, the satisfaction for neighboring road situation is directly related to inhabitants' intention of moving out. Second, the satisfaction for resevation of the parking lot outside a site, is not directly related to inhabitants' intention of moving out, but indirectly related to the intention when that evaluation criterion is combined with the other criteria, and, what is more, the degree of relation to the intention is raised.
\end{abstract}

Keywords : Townscape Husbandry District, Satisfaction for Residential Environment, Intention of Moving out, Fuzzy Analysis, Choquet Integral, Fuzzy measuring

景観形成地区、居住環境に対する満足度、転居意向、ファジィ分析、ショケ積分、ファジィ測度

1. はじめに

\section{1-1 研究背景・目的}

金沢市は江戸時代から城下町として発展してきた伝統的都市である就》。 現在においても、町の伝統的特性を支えていくため、金沢中心部を中心 に保存地区指定等の法規制を推進しており、約7割程度が景観形成地区 に指定されている。しかし、近年、金沢中心部において、人口の継続的 な転出と高齢化が進み、空地、空家が散在している。国勢調查によると、 金沢中心部はこの 35 年間転出人口の增加により人口が半減し、また 65 歳以上の人口が約2割を占めている。また、金沢中心部は城下町と空間 的に重複し、かつ非戦災都市であって、都市構造・土地利用は基本的に 城下町時代の道路パターンと宅地割りの上に成り立っているため文㣮2)、 $4 \mathrm{~m}$ 未満の狭小道路が約 4 割を占めており、狭小規模の青空駐車場・空 地・空家が 3,000 余り分布している文献3)。さらに、保存および景観形成 地区指定等の法規制により、12〜15mの高さ規制、用途の制限、意匠に 関する基淮等が設けられている畆4)。金沢市は、平成 12 年「まちなか 定住促進条例」を制定し定住人口の拡大に取り組んでいるが、特に、こ の高さの規制は最近人口転出の歯止めとなる都心部の分譲マンションの 立地を規制している文献5)

金沢市の人口の減少について、多く研究がなされているが、有効な方 策は充分見出されているとは言えない。景観形成地区などの建物規制 は、都市の物理的また空間的な継続性に有効に働くと考えられるが、必
ずしも居住者の居住の継続性を支持しているとは限らず、そのために 様々な問題点を内包していると考えられる。居住者が自分の居住地域に 対して良好な満足状態を保持しながら、すなわち地区や地域と安定的な 関係を保ちながら、居住できることが望まれることは言うまでもない。 そこで、本論では地区の特徴的な項目についての満足度の構造を分析 し、転居意向との関連を従来の多変量解析による分析に加えてファジィ 分析を行い、転居意向への相乗・相殺効果を明らかにすることを目的と する。居住環境において居住者の転居意向と満足度の関連性を分析する ことは、今後の伝統的な都心居住を考えるうえでの一助となると考えら れる。

1-2 既往の研究

関連する分野として、金沢中心部の研究、転居意向と居住環境の評価 の研究、そしてファジィ分析がある。

金沢中心部の研究において、谷他文解6) は続いている人口の诚少を指 摘し、それは搪大市街部への転居出と世帯分離によるものと推計してい る。川上他婻つは定住志向別に住宅および生活環境に関する満足度の プロフィール分析を行い住宅評価を形成する住宅条件の方がより大き な影響を与えていると推定している。また川上他文献》は地区特性と人 口移動の関わりを探るため重回帰分析を通じ、人口移動の傾向は各地区 特性の差と年齢階層により異なることを説明している。転居意向と居住 環境評価の関倸についての研究では、秦文献9は平地農村の地域住民を

* 京都大学大学院工学研究科 大学院生.工修

** 京都大学大学院工学研究科 教授・工博

*** 京都大学大学院工学研究科 助手. 工博

**** 広島女学院大学生活科学部 教授. 工博
Graduate Student, Graduate School of Engineering, Kyoto University, M. Eng.

Prof., Graduate School of Engineering, Kyoto University, Dr. Eng.

Instructor, Graduate School of Engineering, Kyoto University, Dr. Eng.

Prof., School of Life Sciences, Hiroshima Jyogakuin University, Dr. Eng. 
对象に町の㻴境条件を明らかにした上で、住民の懪境評価と定住意向を クロス分析し、䎐居を促す条件として、成人を対象にした場合は施設利 用や買い物が不便であること、生活環境が悪いこと、また中高生を対象 にした場合は倠く場所が少ないことを指摘している。㚞川朝109は人口 の高齢化が進み若年層の定着が大きな課題となっている展山村を対象 に、綟少年の志向する捏出タイプ別に居住環境に対する評価の平均プロ フィールを分析し、定住志向者の定着と㷌逯予定者の帰罯にとって、就 労場所の確保、生活環境の整備、交通渨境の整備が重要であることを明 らかにしている。天野他的们は長野市を対象に定住希望者、䎐居希望 者、䎐居者の3者による住環境意識から、地方都市中心部の人口減少の メカニスムを、住環境に不渶を持つ居住者が住宅の改善の制約と仕亨上 の都合で郊外人䎐居するという図式で捉えている。これらの研究では㲦 居意向にかかわる居住㻴境評価要因として生活の利便性および住宅条件 に対する居住者の評価をあげている。その他、謓居意向に関する研究

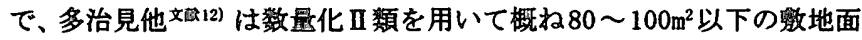
程の一戸建住宅で鞋居意向は强くなることを明らかにしている。

以上の研究ではいずれも謓居意向と人口転出の要因の単独な閣係のみ を明らかにしている。しかし、居住者の転居意向は複数の要因の複合的 な作用によるものと考えられる。1つの目的变数に対し複数の説明变数 が複合的に作用した評価橉造を引き出す分析方法としてファジィ分析が ある。ファジィ分析に関する研究では、宮腰他就 ${ }^{13)}$ は天井高、幅、舆 行きの 3 属性の変化による高さ感の評価杵造をファジィ測度を用いて ファジィ分析し、高さ感に対して幅と舆行きは直接的寄与は小さいが、 この2属性の相互作用および天井高との相互作用により、高さ感に相采 作用することを明らかにしている。また、位寄他视 14) はファジィ分析 を用いて都市内空地に対し、開放感、快適性等の形容詞句に対する評価 と総合評価である魅力度の評価の関保策造を把握している。

上記の研究に邿して本綸は、居住者の渵足度と耺居意向を、従来主と して多変量解析 (相関分析、判別分析等)で捉えられてきた方法に加え て、ショケ稓分型雪回㛿式を用いたファジィ分析を行い、その閶係を渵 足度項目間の相乘・相殺効果と捉えるところに特徽がある。

\section{2. 研究の方滛}

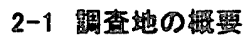

1965年から1995年まで の 30 年間で、金沢中心 部の人口は半減してい 万始4) (図 1)。本調查で 対象とする地区は、前 述した金沢中心部の金 沢景観形成地区のうち、 $\mathrm{JR}$ 北陸線と㳟川，浅野 川に囲まれた地区と東 山地区にある (図2)。こ の地区の中で「芳斉」、 「東山小、材木小、「十三

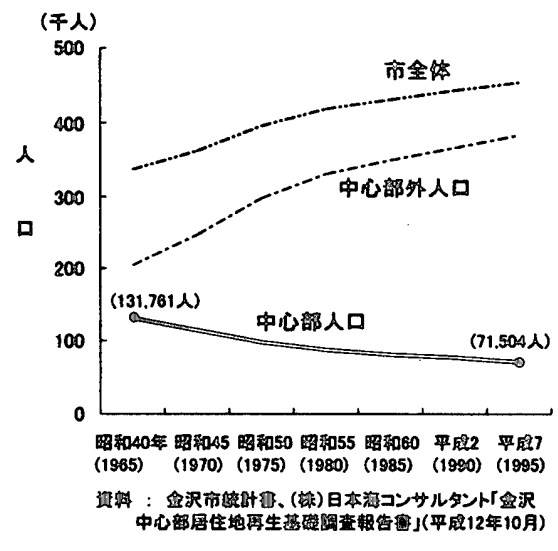

图 1 金沢苚の人口㽖鹃
間等」、「石引」の 5 地区を対象とする。

\section{2-2 铜㸖方法}

地区別に100世帯、総500世帯に対し転居意向と居住環境に対する満 足度について、アンケート調查 (調㚗方法 : 留圈自記式、調㚗期間 : 平 成 12 年 8 月 18 日〜29日)を行った。

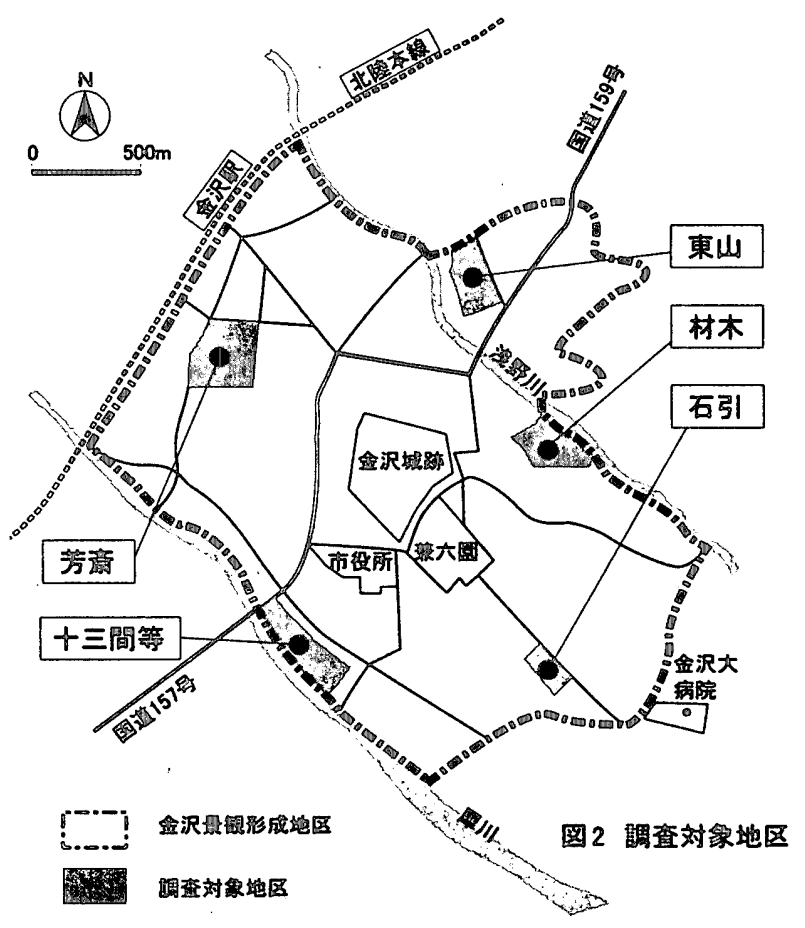

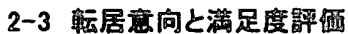

䎐居意向については、「定住を考えている」と「転居を考えている」に 分けた場合、「定住を考えている」に最も近いと考えられる「住み繶け たい」を1、「転居を考えている」に最も近いと考えられる「5年以内 に住みかえる」を5と、5つに分けた。居住棵境評価については、設定 した 16 項目に対し日頃の満足度評価を行った。渵足度は「満足」、「や や满足」、「やや不満」、「不満」の 4 段階評価を用いた（表 1)。

$$
\text { 泰1 アンケート調盗の主な項目 }
$$

\begin{tabular}{|c|c|c|c|c|c|}
\hline \multirow[t]{2}{*}{ （院思计阙） } & \multicolumn{3}{|c|}{ 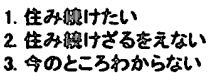 } & \multicolumn{2}{|c|}{ 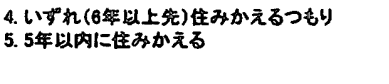 } \\
\hline & & 㳏足 & やや沙足 & やや不沜 & 不湻 \\
\hline & & 1 & 2 & 3 & 4 \\
\hline 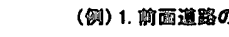 & 蝒周 & $L$ & $\perp$ & $\perp$ & لـ \\
\hline \multicolumn{6}{|l|}{ 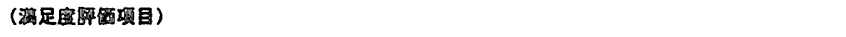 } \\
\hline 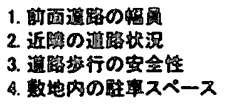 & \multicolumn{3}{|c|}{ 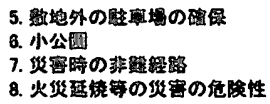 } & 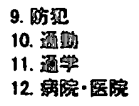 & 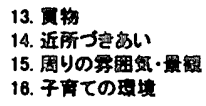 \\
\hline
\end{tabular}

以上の方法で得られたデータに対し、転居意向別満足度評価の特徴、 际居意向と各满足度項目に対する評価の相関、転居意向と満足度項目に 対する評価の回㛿分析、そして渵足度項目に対する評価の因子分析を行 い坛居意向に対して説明力の大きい評価項目を抽出する。抽出した訐 価項目については評価項目間の組み合わせによる評価と転居意向との関 連度を、ファジィ測度を用いて把握する。

\section{3.アンケート調不に対する回答の特性}

アンケート調査で得られた回答の特性は以下のようにまとめることが できる。アンケート調查票の配布数および有効回収率は表 2 に示す。

\section{翡2 アンケート調査数及び有効回収率}

\begin{tabular}{|c|c|c|c|c|c|}
\hline 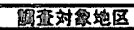 & 匜布政 & 回虾隺 & 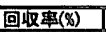 & 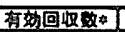 & 效回吸雨( \\
\hline 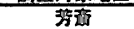 & 100 & 74 & 74 & 56 & 56 \\
\hline 露山 & 100 & 73 & 73 & 33. & 33 \\
\hline 初 & 100 & 72 & 72 & 42 & 42 \\
\hline 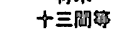 & 100 & 70 & 70 & 39) & 39 \\
\hline 石引 & 100 & 67 & 67 & 33 & 33 \\
\hline sit & 500 & 356 & 71 & 203 & $\frac{\pi}{41}$ \\
\hline
\end{tabular}

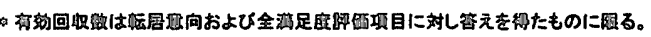




\section{3-1 回答者の特性の概要}

回答者の属性を全体的にみると、女性より男性が約 $20 \%$ 多く、年齢 は $40 \cdot 50$ 代が約 $51 \%$ 、61 歳以上が約 $24 \%$ を占める（表 3)。家族内に 65 歳以上の高龄者のいる世帯は全世帯の約 $44 \%$ 、そのうち高齢者のみ の世帯が $8.4 \%$ を占める（表 4)。住宅の構造は、約 $81 \%$ が木造である (表 5)。入居時期は 1991 年以降が約 $25 \%$ と最も多く、次に $1951 \sim 1960$ 年の間が約 $17 \%$ と多い。生まれてからずっと居住している定住人口は 全体の約 3 割を占める (表6)。自家用車を所有している割合は $80 \%$ を超 える。2台以上の車を所有している割合も約 $41 \%$ にのほる(表 7)。

\section{3-2 転居意向別満足度評価の特街}

回答者の転居意向 ${ }^{\text {法1) }}$ は「住み続けたい」の割合が全体の約 $49 \%$ と、 回答者の約半数が定住を考えている傾向がある（表 8)。転居意向別の

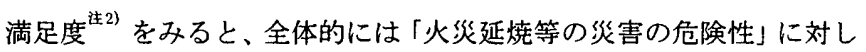
不満度が高く、「住み続けたいと回答した者は「近所づきあいりに対 し満足度が最も高い。「いずれ（6年以上先）住みかえるつもり」と「5 年以内に住みかえる」と回答した者はその他の意向に比べ、特に「敷地 内の駐車スペース」に対し満足していない傾向があることがわかった (図3）。転居意向別居住環境に対する満足度のプロフィールからわかる のは、住み続けざるをえないと回答した者の満足度傾向はむしろい ずれ（6年以上先）住みかえるつもり」と「5年以内に住みかえる」に 近いということである。以上の結果をふまえ転居意向と満足度の関係を なるべく明確な構造として捉えるため、転居意向の項目を「住み続けた いは「定住を考えている」に、「今ところわからないは変わりな く「今のところわからないに、「住み続けざるをえない・「いずれ $(6$ 年以上先) 住みかえるつもり」・「5年以内に住みかえる」は「転居を考 えている」に組替えて3分類にし、転居を考えるほど満足度評価值が大 きくなるように1、2、3の評価得点を与え直した（表 9)。

\section{3-3 転居意向と満足度評価項目の相関}

転居意向と居住環境に対する満足度評価項目のピアソンの相関係数を 用いた相関分析を行った。転居意向に対し1\%水準で有意な項目は、相 関係数の大きい評価項目から「周りの䨌囲気・景観」、「近隣の道路状 況」、數地内の駐車スペース」、「道路歩行の安全性小、近所づきあい」

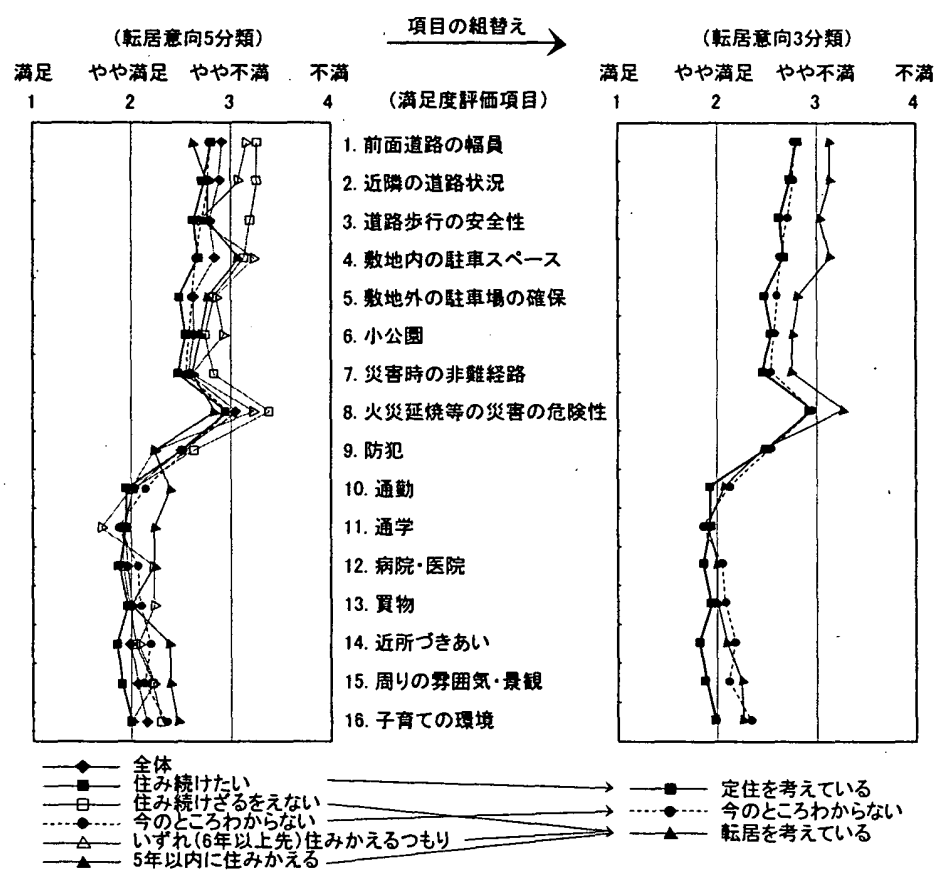

図3 転居意向別評価項目に対する満足度のプロフィール
表3 回答者の年齢の分布

\begin{tabular}{|c|c|c|c|c|c|c|c|c|}
\hline & $11 \sim 20$ & $21 \sim 30$ & $31 \sim 40$ & $41 \sim 50$ & $51 \sim 60$ & $61 \sim 70 \mid$ & $71 \sim 80$ & 合計 \\
\hline 回答者全体 $(\%)$ & 0.5 & 7.9 & 15.8 & 29.2 & 22.3 & 14.4 & 9.9 & 100.0 \\
\hline \multicolumn{9}{|c|}{ 表4 家族内の高齢者の有無 } \\
\hline 可答者全体 $(\%)$ & 65歳上 & L上の方 & $\frac{\text { 夰いる }}{44}$ & 65歳以 & 上の方か & 《いな & & 鼓 \\
\hline
\end{tabular}

表 5 住宅構造の分布

\begin{tabular}{|c|c|c|c|c|c|c|c|c|}
\hline & $\begin{array}{c}\begin{array}{c}\text { 木造 } \\
\text { (在来工洼) }\end{array} \\
\end{array}$ & \begin{tabular}{|l|} 
プレバ \\
(木筫系)
\end{tabular} & 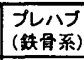 & \begin{tabular}{|c|} 
M-ハi \\
$7 x-$
\end{tabular} & 铁骨造 & RC造 & その地 & 合斯 \\
\hline 回答者全体 $(\%)$ & 80.5 & 1.0 & 1.0 & 1.5 & 13.1 & 2.5 & 0. & 100.0 \\
\hline
\end{tabular}

表 6 入居時期の分布

\begin{tabular}{|c|c|c|c|c|c|c|c|c|c|c|c|}
\hline & $\left.\right|_{\sim 30} ^{1921}$ & $\mid \begin{array}{l}1931 \\
\sim 40\end{array}$ & & $\begin{array}{l}941 \\
550\end{array}$ & {$\left[\begin{array}{l}1951 \\
\sim 60\end{array}\right.$} & $\mid \begin{array}{l}1961 \\
\sim 70\end{array}$ & $\sim \underset{\sim 80}{1971}$ & $\begin{array}{l}1981 \\
\sim 90\end{array}$ & $\left.\right|_{2000} ^{1991 \sim}$ & 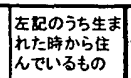 & \\
\hline 回答者全体(\%) & 3 & & 4.0 & $\overline{104}$ & 174 & 8 & 14 & \begin{tabular}{l|l}
9 \\
\end{tabular} & 254 & $4 \mid 274$ & \\
\hline
\end{tabular}

表 7 自家用車の所有状況

\begin{tabular}{r|r|r|r|r}
\hline 回答者全体(8) & 家用車所有 & 自家用車末所有 & 左記のうち2台以上所有 & 合部 \\
\hline 84.7 & 15.3 & 41.4 & 100.0 \\
\hline
\end{tabular}

表 8 調査地の転居意向の傾向

\begin{tabular}{|c|c|c|c|c|c|c|}
\hline 理查対象地区 & 住み繶けたい & $\begin{array}{c}\text { 住み続けさるる } \\
\text { をえない }\end{array}$ & $\begin{array}{l}\text { 今のところ } \\
\text { わからな }\end{array}$ & $\begin{array}{l}\text { Wすれh(6年以 } \\
\text { 上先)住み } \\
\text { かえるつも以 }\end{array}$ & $\begin{array}{l}\text { 5年以内人 } \\
\text { 住みかえる }\end{array}$ & 合都 \\
\hline 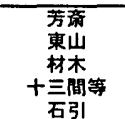 & $\begin{array}{l}27 \\
15 \\
24 \\
15 \\
19\end{array}$ & $\begin{array}{r}11 \\
10 \\
11 \\
6 \\
8\end{array}$ & $\begin{array}{r}15 \\
1 \\
1 \\
11 \\
3\end{array}$ & & & $\begin{array}{l}56 \\
33 \\
42 \\
39 \\
33\end{array}$ \\
\hline$\frac{151}{\text { 全体(x) }}$ & $\frac{19}{100(49.2)}$ & $\frac{8}{46(22.7)}$ & $31(15.3)$ & $\frac{1}{13(6.4)}$ & $13(6.4)$ & $203(100)$ \\
\hline
\end{tabular}

表 9 項目の組替えによる転居意向の3 分類

\begin{tabular}{|c|c|c|c|c|}
\hline 眮查対象地区 & $\begin{array}{l}\text { 定住を } \\
\text { 孝えいるる }\end{array}$ & $\begin{array}{l}\text { 今のににろ } \\
\text { 引からない }\end{array}$ & $\begin{array}{l}\text { 祬居を } \\
\text { 考えいる }\end{array}$ & 合斯 \\
\hline 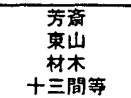 & $\begin{array}{l}27 \\
15 \\
24 \\
15\end{array}$ & $\begin{array}{r}15 \\
1 \\
1 \\
11\end{array}$ & $\begin{array}{r}14 \\
17 \\
17 \\
13\end{array}$ & $\begin{array}{l}56 \\
33 \\
42 \\
39\end{array}$ \\
\hline & 19 & & $\frac{11}{75(255)}$ & 33 \\
\hline
\end{tabular}

表10 転居意向と满足度評価項目の相闋分析

\begin{tabular}{|c|c|c|}
\hline 評価項目 & 相関係数 & 有意確率 \\
\hline 1.前面道路の幅貣 & $0.168 *$ & 0.017 \\
\hline 2. 近隣の道路状況 & $0.220 * *$ & 0.002 \\
\hline 3.道路步行の安全性 & $0.202 * *$ & 0.004 \\
\hline 4.橎地内の駐車スペース & $0.211 * *$ & 0.003 \\
\hline 5.敷地外の駐車埸の確保 & $0.171 *$ & 0.015 \\
\hline 6.小公圍 & 0.106 & 0.133 \\
\hline 7.災要時の避難経路 & $0.162 *$ & 0.021 \\
\hline 8.火災延焼等の災害の危晚性 & $0.168 *$ & 0.017 \\
\hline 9.防犯 & -0.006 & 0.931 \\
\hline 10.通勤 & 0.091 & 0.198 \\
\hline 11.通学 & -0.008 & 0.908 \\
\hline 12.病院·医院 & 0.098 & 0.166 \\
\hline 13.買物 ， & 0.040 & 0.575 \\
\hline 14.近所づきあい & $0.185 * *$ & 0.008 \\
\hline 15.周りの军囲気・景観 & $0.224 * *$ & 0.001 \\
\hline 16.子亩ての䍗境 & $0.176 *$ & 0.012 \\
\hline
\end{tabular}

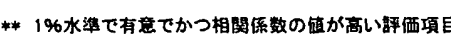

* 596水染で有畫でかつ相関保数の犆が高い訣洒項目

表11 転居意向と満足度評洒項目の重回㷌分析

\begin{tabular}{|c|c|c|c|c|c|}
\hline \multirow{2}{*}{\begin{tabular}{|l|l} 
評価項目 & 係数 \\
\end{tabular}} & \multicolumn{2}{|c|}{ 非䙐準化係数 } & \multirow{2}{*}{$\begin{array}{c}\text { 祭準化係数 } \\
\wedge-4\end{array}$} & \multirow[b]{2}{*}{$\mathbf{t}$} & \multirow{2}{*}{ 青意確率 } \\
\hline & $B$ & 標準韵总差 & & & \\
\hline (定数) & 0.238 & 0.385 & & 0.619 & 0.536 \\
\hline 1.前面道路の幅員 & -0.015 & 0.101 & -0.014 & -0.147 & 0.883 \\
\hline 2. 近隣の道路状況 & 0.116 & 0.116 & $0.106 *$ & 0.997 & 0.320 \\
\hline 3.道路歩行の安全性 & 0.103 & 0.096 & $0.100 *$ & 1.079 & 0.282 \\
\hline 4.數地内の駐 & 0.097 & 0.074 & $0.105 *$ & 1.319 & 0.189 \\
\hline 5.数地外の駐 & 0.102 & 0.078 & $0.101 *$ & 1.310 & 0.192 \\
\hline 6.小公園 & -0.062 & 0.082 & -0.061 & -0.746 & 0.457 \\
\hline 7.災害時のi & 0.112 & 0.092 & 0.099 & 1.220 & 0.224 \\
\hline D災害の危険性 & 0.034 & 0.095 & 0.030 & 0.361 & 0.719 \\
\hline 9.防犯 & -0.182 & 0.088 & $-0.166 * *$ & -2.064 & 0.040 \\
\hline 10. 通勤 & 0.044 & 0.112 & 0.036 & 0.390 & 0.697 \\
\hline 11. 通学 & -0.197 & 0.122 & $-0.153 *$ & -1.608 & 0.110 \\
\hline 12.病院·医院 & 0.176 & 0.115 & $0.139 *$ & 1.536 & 0.126 \\
\hline 13.買物 & -0.059 & 0.092 & -0.054 & -0.641 & 0.522 \\
\hline 14.近所づきる & 0.075 & 0.119 & 0.055 & 0.627 & 0.532 \\
\hline 15.周りの罍囲気・景钼 & 0.202 & 0.112 & $0.155 *$ & 1.809 & 0.072 \\
\hline 16.子育ての瓄境 & 0.103 & 0.110 & 0.082 & 0.943 & 0.347 \\
\hline & & & 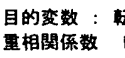 & & \\
\hline
\end{tabular}


である。また、 $5 \%$ 水準で有意な項目は、相関係数の大きい評価項目か ら「子育て環境」、敷地外の駐車場の確保」、「前面道路の幅員」、「火災 延焼等の災害の危険性」「災害時の非難経路」である（表 10）。

\section{3-4 転居意向之満足度評価項目の重回帰分析}

転居意向と居住環境評価項目に対する満足度の予測值が観測值の転居 意向にどれほど適合しているかを調べるために回㷌分析を行った。その 結果、全体の評価項目の中では「防犯」の回㷌保数が最も大きく、「周 りの雾囲気・景観」、「通学小、病院・医院」、「近隣の道路状況」、「敷地 内の駐車スペース」、敷地外の駐車場の確保、「道路歩行の安全性」が その後に続く。重相関係数は 0.414 であった(表 11$) 。$

\section{3-5 回答者の満足度評価構造}

満足度評価項目の因子分析を行い、回答者の満足度は5つに分けられ ることがわかった。また、各因子別に評価項目の内容をみて、第1因子 は「車の通行」の軸、第 2 因子は「日常生活の利便」の軸、第 3 因子は 「近所」の軸、第 4 因子は「犯罪」の軸、第 5 因子は「災害の危険」の 軸と解秎する文献 15$)$ ことができた(表 12)。

\section{3-6 転居意向の説明変数となる満足度評価項目}

転居意向と高い相関係数または回䚻係数を持ち、互いに相関はなるべく 小さい評価項目を説明変数とするモデルを目指す。この際、4章に行う ファジィ分析において、転居意向に対する説明変数間の組み合わせによ る満足度の相乗・相殺効果を明らかにするためには、説明変数に対する 満足度評価々転居意向は比例関係にある必要がある。まず、上述の相関 または回㷌分析の結果からは「前面道路の幅員」、「近隣の道路状況小、 「道路歩行の安全性」、敷地内の駐車スペース」、敷地外の駐車場の確 保」、「災害時の避難経路」、「火災延焼等の災害の危険性」、「防犯」、「通 学小、病院・医院」、「近所つききい小「周りの雾囲気・景観」、「子育て の環境」が転居意向の説明変数の候補として考えられる(表10、11)。次 に、これら全てを選択する場合、表 12 の「近隣の道路状況」、「前面道 路の幅員」、「道路歩行の安全性」「敨地内の駐車スペース」のように、 同じ因子内で負荷量が高い場合、説明変数間に高い相関を持つ場合が生 じる。したがって、転居意向との高い相関係数や回㷌係数を考えると 「近隣の道路状況」、「通学」、「周りの雲囲気・景観」、「防犯」、「敷地外 の駐車場の確保了、「災延莾等の災害の危険性」が説明変数として有力 である。最後に、説明変数となる満足度評価項目は、転居意向との相関 係数および回㷌係数が正 $(+)$ の值を持つ必要もあることから、ファジィ 分析では「防犯」、「通学」は除外した。

これらの条件から、満足度が低下するほど転居意向が高くなる「近隣 の道路状況」、「周りの雾囲気・景観了、教地外の駐車場の確保小、「火災 延焼等の災害の危険性」の4つの満足度評価項目をファジィ分析の説明変 数とした(図 4)。

\section{4. 転居意向に対する満足度評価項目間の組み合わせによる効果の ファジィ分析}

3-6で選び出した説明変数に基づいて、説明変数間の複合的評価と 転居意向の関連度が説明できるファジィ測度を用いたファジィ分析を 行った。

\section{4-1 ファジィ測度による分析の理由}

複数の要因は個別的に転居意向と相関するだけでなく、複合的に相 互作用すると考えられる。本論は、居住環境に対する満足度が転居意 向に関係があると考え、評価項目間の複合的満足度と転居意向の関連 度を分析する。そのためには起こり得る評価項目間の複合的満足度と
表12 満足度評価項目の因子分析による因子行列

\begin{tabular}{|c|c|c|c|c|c|c|}
\hline \multicolumn{2}{|c|}{ 撞価項目 } & 第1因子 & 第2因子 & 第3因子 & 第4因子 & 第5因子 \\
\hline \multicolumn{2}{|c|}{ 2]近䑝の道路状況*** } & $0,890 *$ & 0.087 & 0.078 & 0.075 & 0.044 \\
\hline \multicolumn{2}{|c|}{ 1前面道路の幅員 } & $0.724 *$ & 0.045 & -0.036 & 0.074 & 0.195 \\
\hline \multicolumn{2}{|c|}{ 3/道路歩行の安全性 } & $0.639 *$ & 0.142 & 0.057 & 0.304 & -0.017 \\
\hline \multicolumn{2}{|c|}{4 敷地内の駐車スペース } & $0.384 *$ & -0.027 & -0.034 & 0.291 & 0.288 \\
\hline \multicolumn{2}{|l|}{12 病院·医院 } & 0.058 & $0.756 *$ & 0.039 & -0.012 & 0.025 \\
\hline \multicolumn{2}{|l|}{11 通学** } & -0.010 & $0.675 *$ & 0.064 & 0.398 & -0.021 \\
\hline \multirow{2}{*}{\multicolumn{2}{|c|}{$\begin{array}{l}13 \\
10 \text { 買通物 }\end{array}$}} & 0.127 & $0.586 *$ & 0.132 & -0.133 & 0.014 \\
\hline & & 0.007 & $0.581 *$ & 0.176 & 0.400 & -0.008 \\
\hline \multicolumn{2}{|c|}{ 15 } & 0.011 & -0.048 & 0.708 * & 0.256 & 0.120 \\
\hline \multicolumn{2}{|c|}{ 16|子育ての瑔境 } & 0.006 & 0.324 & $0.664 *$ & -0.034 & 0.108 \\
\hline \multicolumn{2}{|c|}{14 近所づきあい } & 0.061 & 0.373 & $0.540 *$ & 0.177 & -0.031 \\
\hline \multirow{2}{*}{\multicolumn{2}{|c|}{ 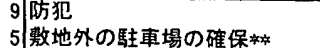 }} & 0.228 & 0.147 & 0.087 & $0.470 *$ & 0.075 \\
\hline & & 0.249 & 0.017 & 0.200 & $0.416 *$ & 0.050 \\
\hline \multicolumn{2}{|c|}{7 災害時の避難経路 } & 0.121 & 0.077 & 0.066 & 0.066 & $0.749 *$ \\
\hline \multicolumn{2}{|c|}{6 小公園 } & 0.062 & -0.041 & 0.428 & -0.023 & $0.489 *$ \\
\hline \multicolumn{2}{|c|}{ 8|火災延焼等の災害の危険性㶱 } & 0.366 & -0.102 & 0.083 & 0.344 & $0.392 *$ \\
\hline \multirow{3}{*}{$\begin{array}{c}\text { 回転後の } \\
\text { 負荷量平方和 }\end{array}$} & & 2.1 & 2.024 & 1.542 & 1.139 & 1.114 \\
\hline & & 13.5 & 12.651 & 9.6 & 7.120 & 6.962 \\
\hline & & 13.515 & 26.166 & 35.801 & 42.921 & 49.884 \\
\hline
\end{tabular}

因子の抽出法は主因子法、回枟法はバリマックス法を用いた。

* 各因子で高い因子角荷䏸

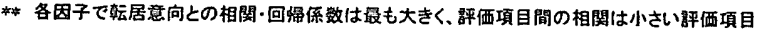

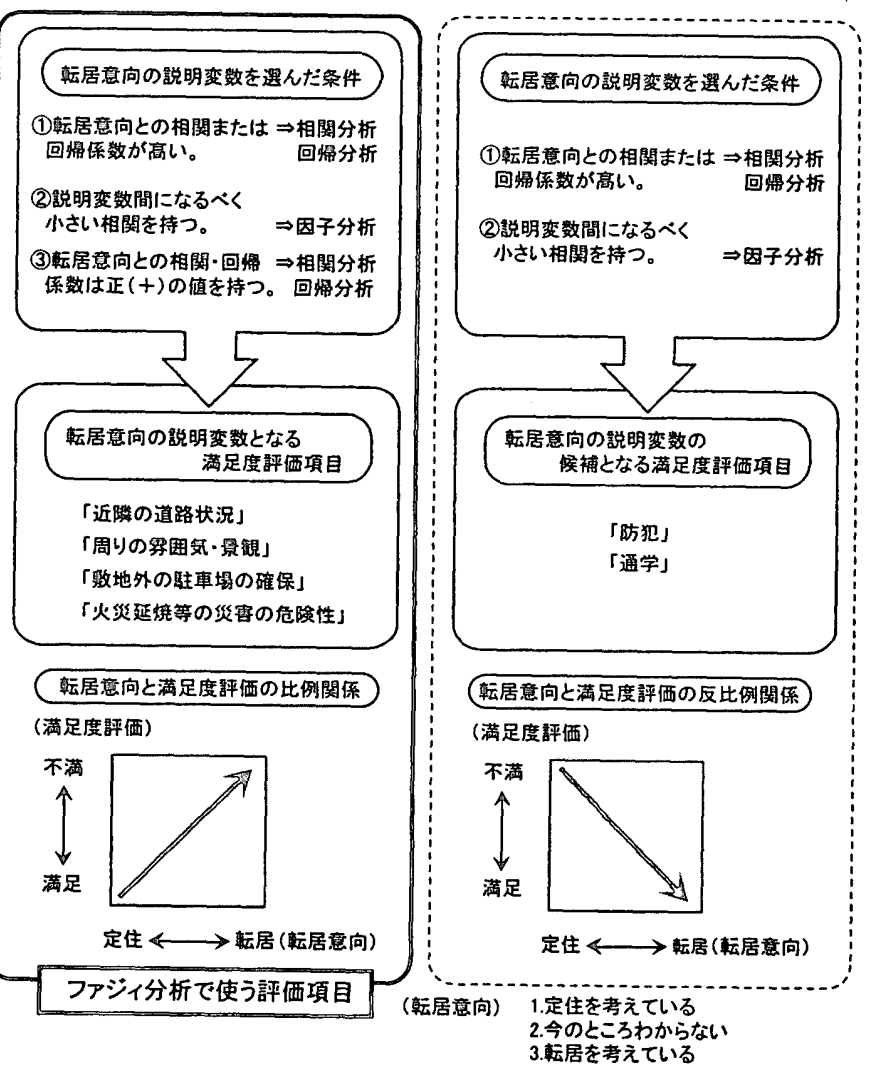

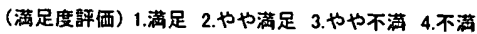

図4多変量解析で得られた転居意向の説明变数

転居意向の関連度を説明する関数が必要である。そこで、本論におい て居住環境に対する満足度と転居意向のデータは、順序尺度注3) とし て扱い、また、この際関連度関数注4) は非加法的である条件を与える ことによって、間隔尺度では得られない関連度の分析が可能となる。 各項目に与えられた評価值を総合して1つの総合評価を得る総合化の 数学的方法として積分があり、特に、総合評価に対して各項目の重要 度の重み付けが非加法的であるため、総合評価值が非加法的な和にな る時には、ファジィ積分がこれに適している。このファジィ積分は、 各項目に対する非加法的な重要度の重み付けであるファジィ測度によ り求められる文补16)。転居意向を総合評価と考えると、関連度関数と してファジィ測度が適していると考えられる。以降では、各満足度評 価項目に対する重み付けと非加法的な満足度との積を足し合わせて転 居意向の評価値を算出するファジィ積分を用い、項目ごとに与えられ 
る転居意向との関連度、すなわちファジィ測度值を求めることによっ て、転居意向と居住環境に対する満足度の関係構造を把握する。

\section{4-2 ファジィ測度とその解䣋}

ファジィ測度は、順序尺度で評価する説明変数の転居意向に対する非 加法的関連度関数とする。ファジィ測度は加法性文新17)、洼5)が仮定されて いないため、ある集合 $A 、 B に$ 対し、 $A \cap B=\phi$ のときの「 $\mu(A \cup B) 」 と$ $\lceil\mu(\mathrm{A})+\mu(\mathrm{B}) 」$ の間の大小関係については、一意に定まらず、以下の いかなる場合も起こり得る。

$\mu(\mathrm{A} \cup \mathrm{B}) \geqq \mu(\mathrm{A})+\mu(\mathrm{B}) \quad$ or $\quad \mu(\mathrm{A} \cup \mathrm{B})<\mu(\mathrm{A})+\mu$ (B)

また、起こり得る3通りの場合のそれぞれについて、次のような解釈 が可能である。

(1) $\mu(\mathrm{A} \cup \mathrm{B})>\mu(\mathrm{A})+\mu(\mathrm{B}): \mathrm{A}$ と B の間に相乗作用がある。

(2) $\mu(\mathrm{A} \cup \mathrm{B})<\mu(\mathrm{A})+\mu(\mathrm{B}): \mathrm{A}$ と B は（ $\mu$ で測っている属性において） 重複をもつ。または、Aと B の間に相殺作用がある。

(3) $\mu(\mathrm{A} \cup \mathrm{B})=\mu(\mathrm{A})+\mu(\mathrm{B}): \mathrm{A}$ と Bは独立で相互作用はない。相乗作用 と相殺作用が互いに打ち消し合っている。

まとめると、「ファジィ測度はその非加法性によって部分集合間の相 互作用 (要素の組み合わせによる効果) を表している」と言える文能18)。 ただし、ここで扱うファジィ測度は、全体集合の測度の值が1とは限ら ないものである。また下記のように数学的に定義される。
(1) $\mu(\phi)=0$
(2) $\mathrm{A} \subset \mathrm{B} \Rightarrow \mu(\mathrm{A}) \leqq \mu$ (B)

ここで(2)はファジィ測度の単調性を表している。しかし、ファジィ測 度の解析において、 $\mathrm{A} \cap \mathrm{B}=\phi \Rightarrow \mu(\mathrm{A} \cup \mathrm{B})=\mu(\mathrm{A})+\mu(\mathrm{B}) 」 か ゙$ 成立する ことから、ファジィ測度は一般的な測度の搪張文藏 17)、注6)であると言え る。すなわち、「一般的な測度Сファジィ測度」である。

このような特性を持つファジィ測度をデータから算出する場合、ファ ジィ測度は、転居意向の観測值と、ファジィ積分式より説明変数の満足 度評価値の和で求まる転居意向の予測值間の差の 2 乗を最小化して求め る方法が用いられている文能16)。これは回帰分析の方法と類似するが、一 般的な線形重回㷌式を用いると目的変数に対する説明变数の個別的な関 連度だけが算出されるため、目的変数に対する説明変数間の相互作用に よる満足度の効果は求まらない。そのため、ファジィ測度は、ファジィ 積分型重回帰式文献1314) とショケ積分型重回帰式文献19) 上り得られる回帰 係数から算出する。本論では、また、説明変数間の相互作用による満足 度評価を別途に行わず、説明変数に対し個別的に行った満足度のデータ から説明変数間の相互作用による満足度を計算するため、ショケ積分型 重回帰式を用いた回帰分析によりファジィ測度を算出する。

\section{4-3 ショケ積分型重回帰式}

目的変数（転居意向）と4つの説明変数に対する評価データを平均値 0.5 、標準偏差 0.1 の非負の単関数に変換させる。変換した説明変数に 対する全サンプルのデータに基づき、ショケ積分式を用いて転居意向の 予測值を算出する。この予測值は、変換した目的変数に対する全サンプ ルのデータを観測値とした時、この観測值と予測値の差を最小化するよ うに算出する文献19)。予測值のショケ積分值は、回答者の各説明変数に 対する満足度評価值を変換したデータを、值が大きい順に並べ替え、最 も小さい值を除き、大きい值から順に2つの説明変数の差を求め、これ らの差とそれに該当するファジィ測度との積の総和である。

以上の内容を数式で定義すると次のようになる。式に使用する記号お よび説明変数の定義は表 13 と表 14 に示す。

$\mathrm{n}$ 番目のサンプルのファジィ測度 $\mu(\mathrm{A})$ に倸わる2つの説明変数の值の
差を $\mathrm{o}_{\mathrm{n}, \mathrm{A}}$ で表す。例えば、 $\mathrm{i}=3$ で、 $\mathrm{s}_{1} \geqq \mathrm{~s}_{2} \geqq \mathrm{~s}_{3}$ の時、

$\mathrm{n}$ 番目のショケ積分式 $\mathrm{C}_{\mathrm{n}}$

$=\left\{\mathrm{s}\left(\mathrm{v}_{\mathrm{i}}\right)-\mathrm{s}\left(\mathrm{v}_{2}\right)\right\} \mu(\{1\})+\left\{\mathrm{s}\left(\mathrm{v}_{2}\right)-\mathrm{s}\left(\mathrm{v}_{3}\right)\right\} \mu(\{1,2\})$

$+s(v) \mu(\{1,2,3\})$

$=\left[\mu(\{1\}) o_{n,\{1\}}+\mu(\{2\}) o_{n,\{2\}}+\mu(\{3\}) o_{n,\{3\}}+\mu(\{1,2\}) o_{n,\{1,2}\right.$

$\left.+\mu(\{1,3\}) o_{n,\{1,3\}}+\mu(\{2,3\}) o_{n,\{2,3\}}+\mu(\{1,2,3\}) o_{n,\{1,2,3\}}\right]$ $\Rightarrow$ ([]の中の式は、 $\mathrm{n}$ 番目のファジィ積分型重回帰式) とする。ただし、

$o_{n, 11}=s(v)-s(v)$.

$\mathrm{o}_{\mathrm{n}, 11.2\}}=\mathrm{s}\left(\mathrm{v}_{2}\right)-\mathrm{s}\left(\mathrm{v}_{3}\right)$.

$o_{n, ~}(1,2,3\}=s\left(v_{3}\right)$

であり、ショケ積分式に現れない。 $\mathrm{n}_{n-1}$ は '0’ と固く。

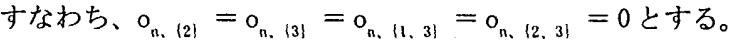

このように表せば、各ファジィ測度を回帰係数とし、正規方程式で求 められることがわかる。したがって、ファジィ積分型重回帰式の形に変 換することによってファジィ測度を求めることができる。本論では、 ファジィ積分型重回帰式の形に変換したショケ積分式を「ショケ積分型 重回帰式」と呼ぶこととする。

\section{4-4 ショケ積分型重回㷌式によるファジィ分析の結果}

ショケ積分型重回帰式を用いて回帰分析 ${ }^{\text {ॠ7) }}$ を行うことにより得られ た各説明変数および説明変数間の複合的評価によるファジィ測度を表 15に示す。ここで重相関係数は0.401であった。まず、説明変数間の組 み合わせ数による満足度と転居意向の関連度であるファジィ測度をみる と、変数間の組み合わせ数が 1 つの場合は\{1\}が 0.131 、組み合わせ数 表13 ファジィ測度の算出時に使用する記号

\begin{tabular}{|c|c|}
\hline 記号 & 意味 \\
\hline $\begin{array}{c}i \\
v_{i} \\
{\left[V_{i}\right]} \\
g\left(\left|V_{i}\right|\right) \\
\mu\left(\left[V_{i}\right\}\right)\end{array}$ & 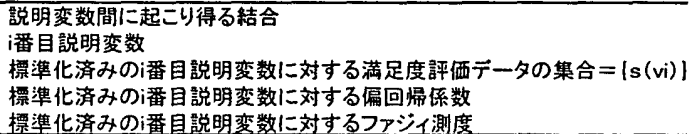 \\
\hline
\end{tabular}

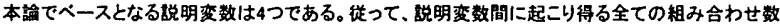

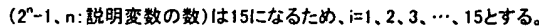

表 14 全説明変数の定義

\begin{tabular}{|c|c|c|c|c|c|c|}
\hline & & & $v_{i}$ & & & \\
\hline$i$ & $\begin{array}{l}\text { (1)近隣の } \\
\text { 道路状況 }\end{array}$ & $\begin{array}{c}\text { (2)周以の } \\
\text { ॠ曲文・累银 }\end{array}$ & $\begin{array}{r}\text { (3)敖地外の } \\
\text { 駐車場の碓保 }\end{array}$ & 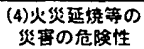 & & $\left\{V_{i}\right\}$ \\
\hline $\begin{array}{l}1 \\
2 \\
3 \\
4\end{array}$ & $5 \quad 0$ & $\begin{array}{l}1 \\
1\end{array}$ & $\frac{1}{7}$ & $\frac{1}{7}$ & 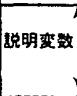 & 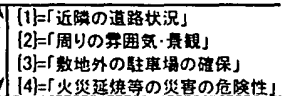 \\
\hline $\begin{array}{c}5 \\
\vdots \\
11\end{array}$ & 0 & 0 & $\begin{array}{l}0 \\
0\end{array}$ & 0 & 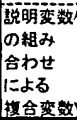 & $\left\{\begin{array}{l}11,2] \\
\vdots \\
{[1,2,3]} \\
\vdots \\
11,2,3,4]\end{array}\right.$ \\
\hline
\end{tabular}

表 15 ショケ積分によるファジィ測度

\begin{tabular}{|c|c|c|c|c|c|}
\hline & 翡摽粱 & 化係数 & *摽準化係数べータ & & \\
\hline & B & 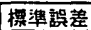 & $: g\left(\left[V_{i} \mid\right)=\mu\left(\mid V_{i}\right\}\right)$ & 有量碓体 & サンクル喓 \\
\hline (定数) & 0.260 & 0.059 & & 0.000 & \\
\hline$[1\}=[$ 近隣の道路状況 $]$ & 0.400 & 0.240 & $0.131 * *$ & 0.097 & 54 \\
\hline (2) $=$ 「周以の慗囲気・累钼了 & 0.063 & 0.195 & 0.026 & 0.748 & 45 \\
\hline 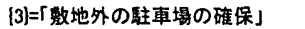 & -0.169 & 0.273 & -0.051 & 0.538 & 71 \\
\hline (4) $=\Gamma$ 火災延焼等の災害の危険性」 & -0.206 & 0.206 & -0.076 & 0.320 & 33 \\
\hline$\{1,2\}$ & 0.169 & 0.431 & 0.030 & 0.695 & 17 \\
\hline$[1,3]$ & 0.044 & 0.229 & 0.014 & 0.846 & 53 \\
\hline$\{1,4\}$ & 0.094 & 0.205 & 0.036 & 0.647 & 44 \\
\hline$[2,3\}$ & 0.766 & 0.333 & $0.189 * *$ & 0.023 & 39 \\
\hline$\{2,4\}$ & 0.164 & 0.274 & 0.047 & 0.549 & 21 \\
\hline$\{3,4\}$ & 0.704 & 0.283 & 0.182 & 0.014 & 29 \\
\hline$[1,2,3\}$ & 0.475 & 0.258 & 0.153 & 0.067 & 53 \\
\hline$(1,2,4)$ & 0.711 & 0.216 & $0.269 * *$ & 0.001 & 47 \\
\hline$[1,3,4\}$ & 0.414 & 0.189 & 0.175 & 0.030 & 68 \\
\hline$(2,3,4\}$ & 0.308 & 0.190 & 0.128 & 0.108 & 35 \\
\hline$[1,2,3,4]$ & 0.468 & 0.110 & $0.397 * *$ & 0.000 & 203 \\
\hline
\end{tabular}




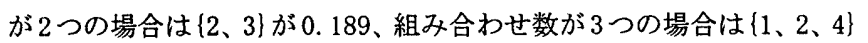
が 0.269 と転居意向と高い関連度を持つ。

次に、4-2節に従い、説明変数間の測度和と、説明変数間の組み合わ せによる複合変数の測度との大小関係を比較し、転居意向に対する複数 の説明変数間の組み合わせによる満足度の相乗·相殺勃果に対する解釈

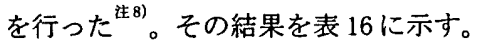

まず、相乗効果をみると、説明変数間の組み合わせ数が 2 つの場合、
転居意向に相殺勃果のある複合変数との組み合わせによっては相乗効果 がある。しかし図5の(6、、(12)のように相乗効果のある複合変数との組み 合わせによっては転居意向に相殺効果がある。

\section{5. まとめと今後の課題}

本論では転居意向への居住環境に対する満足度の関係を明らかにする ため、多変量解析によって選んだ「近隣の道路状況小、「周りの雲囲気・
\{2\}と\{3\}の組み合わせによ る $\{2 、 3\}$ と、 $\{3\}$ と $\{4\}$ の組 み合わせによる\{3、4\}は転 居意向に相乗効果がある。 組み合わせ数が3つの場合、 複合变数 $\{1 、 2 、 4\}$ は確実に 転居意向に相乗効果がある。 また、組み合わせ数が2であ る複合変数が転居意向に対 して相殺効果がある場合、 $\{1\} 、\{2\} 、\{3\} 、\{4\}$ との組み合 わせによって転居意向に相 乗効果がある。最後に、相殺 効果をみると、説明変数間 の組み合わせ数が 2 つの場 合、\{2\}、\{3\}、\{4\}は\{1\}との組 み合わせによって転居意向 に相殺効果がある。また、組 み合わせ数が3つの場合、組

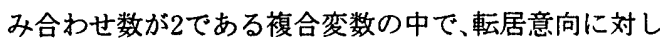
て相乗効果のある $\{2 、 3\}$ と $\{3 、 4\}$ は、 $\{1\} 、\{2\} 、\{4\}$ との 組み合わせにより、転居意向に相殺効果がある(表 $16 、$ 図 5)。

以上の結果を要約すると、次の通りである。 (1)「1. 近隣の道路状況」の満足度は、転居意向に単独 では最も高い関連度を持ち、「1. 近隣の道路状況」に対 して不満足ほど回答者の転居意向は高くなる。しかし、 図 5 の(1)〜(4)と(7)〜(10)ように「2. 周りの雾囲気・景 観」、「3. 敷地外の駐車場の確保」、または「4. 火災延焼 等の災害の危険性」との組み合わせによって、転居意 向に相殺効果がある。

（2）「3. 敷地外の駐車場の確保」の满足度は、転居意向 に単独では高い関連度を持たないが、図5の(5)〜(6)、(11) 〜12)のよに「2. 周りの雲囲気・景観」または「4. 火 災延焼等の災害の危険性」との組み合わせによって、転 居意向に相乗効果がある。また、「3. 敷地外の駐車場の 確保」の満足度は、相殺効果のある複合変数「1. 近隣 の道路状況、2. 周りの雲囲気・景観」、「1. 近隣の道路 状況、4. 火災延焼等の災害の危険性小、「2. 周りの雾囲 気・景観、4. 火災延焼等の災害の危険性」との組み合 わせによって、転居意向に相乗効果がある(図 5 の1、 (8)、(10)。

（3）「2. 周りの雾囲気・景観」と「4. 火災延焼等の災害 の危険性」の満足度は、図5の(2)〜(5)、(7)、(11)のように

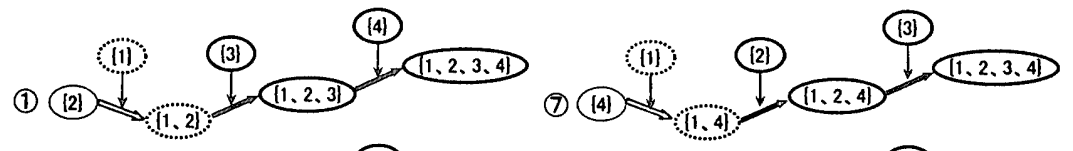

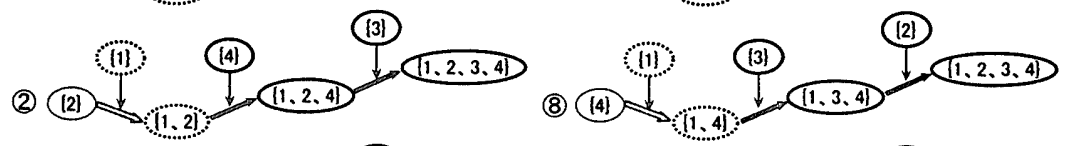

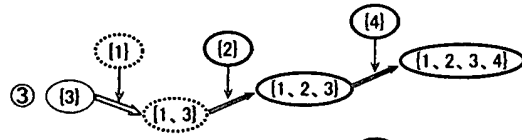

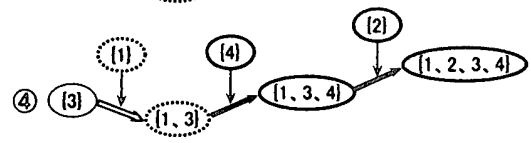

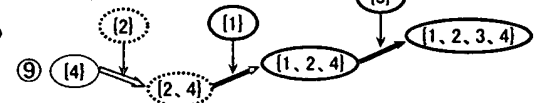

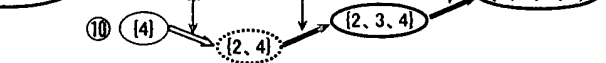

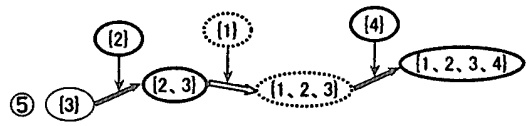

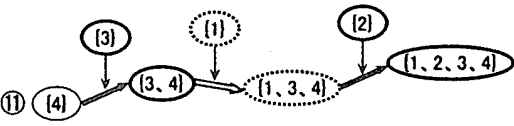

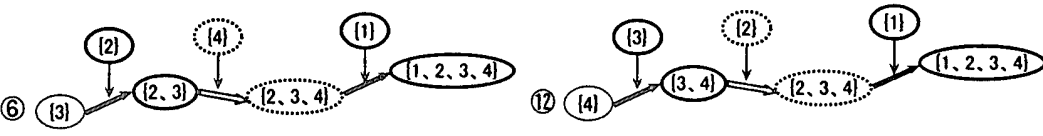

(1) (12)には变数の测度の相対的大小関伱を图示

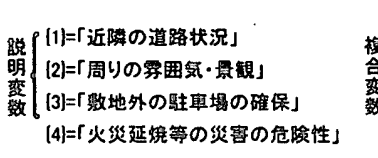

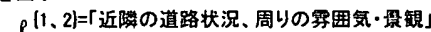

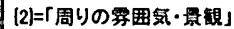

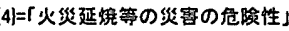

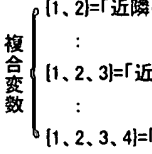

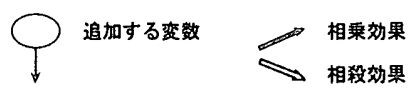
火災延偾等の災㝒の危除性。

图 5 彰居意向に対して相乗・相殺効果のある变数 
景観」、「敷地外の駐車場の確保」「火災延焼等の災害の危険性」の4つ の満足度評価項目をもってファジィ分析を行った。その結果より、本論

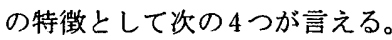

1) 全説明変数に対する不満が高くなると相乗的に転居意向が高くなるこ とが分かり、これは多変量解析では得られない知見である。

2)相関分析の結果では「周りの雲囲気・景観」の満足度が転居意向と最 も高い相関を持つ。これに加えてファジィ分析を行った結果、「近隣の 道路状況」の満足度が転居意向に単独で最も高い関連度を持つことがわ かった。

3）16の満足度評価項目と転居意向を重回帰式を用い、回帰分析を行っ て得られた重相関係数は 0.414 であった。これに対し、この16の評価 項目から選んだ 4 の説明変数と転居意向をショケ積分型重回㷌式を用 いファジィ分析を行って得られた重相関係数は 0.401 であった。つま り、説明変数 16 項目の重回㷌式の重相関係数と、より少ない説明変数 4項目のショケ積分型重回㷌式の重相関係数にはあまり差がない。

4)ファジィ測度で説明変数間の組み合わせによる効果を捉えることによ り、「敷地外の駐車場の確保」のように転居意向に単独では関連度が高 くないが、他の変数との組み合わせによって転居意向との関連度をあげ る満足度評価項目も明らかにした。

5)「近隣の道路状況」、敷地外の駐車場の確保」の満足度は複合すると 転居意向に対して相殺効果を持つが、それに他の条件が加わると相乗効 果が見られた。調査地が城下町の狭い道路パターンであって、回答者の 殆どが自家用車を所有しているので、「近隣の道路状況了、「敷地外の駐 車場の確保」は複合しても転居意向に対して相乗効果を持たないと考え られる。

ファジィ分析は集合の組み合わせをすべて扱うため、n個の説明変数 では組み合わせが $2^{n}-1 に$ 増加する。したがって、多くの変数の組み合 わせによる分析は困難である。また「防犯小「通学」のように満足度が 向上しても転居意向が高くなる項目については今回の分析では解明でき なかった。この原因についての分析が今後の課題である。

\section{謝辞}

アンケート調查の実施には「じゅう・総合計画研究所」の協力を得た。 じゅう・総合計画研究所と設問にご協力頂いた金沢中心部の居住者の 方々に厚くお礼を申し上げたい。

注

注1) $5 つ に$ 分けた転居意向の評伍得点は「住み続けたいりを1、「5年以内に住み かえる」を 5 と、1〜5の数字で便宜的に割り振った。

注2)满足度は「満足小、队队満足了、「队や不満小「不满」の 4 段階評価を用いて、 これらの評価得点はまた1〜 4 の数字で便宜的に割り振った。

注3）順序尺度 (Ordinal scale) は対象とする事象の大小関俰を基に数值を与え る規則である。多変量解析による分析では、図3、表10、11で用いたデー夕は連 続変量として扱った。しかし、本論では、ファジィ分析を行い、相乗・相殺効果 といった説明変数間の組み合わせによる効果を捉えるため、データの単調性のみ に着目し、間隔尺度ではなく順序尺度文就 17) 20) として扱い、この関係を再度分析 しなおした。

注4) 転居意向に対する説明变数の関連度を説明する関数を略して関連度関数と 筆者が定義する。

注 5) 測度の一般的性質について参考文献 17) から引用する。

ある集合A、Bに対し、

(1)加法性: 測度の本質は、その加法性にある。加法性を数式で書くと

$\mathrm{A} \cap \mathrm{B}=\phi \Rightarrow \mu(\mathrm{A} \cup \mathrm{B})=\mu(\mathrm{A})+\mu(\mathrm{B})$ となる。

(2)非負性 : 測度の值は非負（正または0）の実数である。ここでは集合の大きさ

として日常的な普通の「大きさ」だけを考えているので、負の值をとるような
「大きさ」は扱わない。

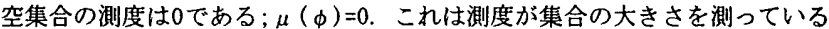
ことから、当然といえる。また、加法性の式で $A=\phi$ とすると、

$\mu(\mathrm{B})=\mu(\phi)+\mu(\mathrm{B})$

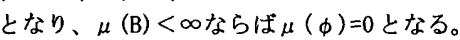

(3)連続性 : 測度のもう一つの性質に連続性がある。これは、集合の微少の変化に 対して、その測度（大きさ）も微少に変化し、急激には変化しないということ である。 測度の連続性は、数学的には

(CFB) $A_{n} \uparrow A \Rightarrow \mu\left(A_{n}\right) \uparrow \mu$ (A)

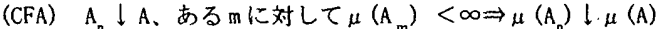

と表現される。(CFB)は下からの連続性、(CFA)は上からの連続性と呼ばれる。 注6)ファジィ測度は、数の集まりや物の集まりに対して1つの数値を与える集 合関数と呼ばれる関数の一種であり文触16)、松下裕文献21) はファジィ娜度を主観 的重視度と解积している。

注7）変換済みのデータの入力および分析はWindows 用のSPSS10.0Jソフトウェ アを用いた。

注8）ただし、本来ファジィ測度は0から1の値を取るが、本分析の結果 $\{3\}$ と $\{4\}$ のファジィ測度がマイナス值であるため、相乗・相殺効果の解釈に限り、\{3\}と\{4\} の測度はその絶対值をもって解釈を行った。

\section{参考文献}

1)二宮哲雄、「金沢一伝統·再生・アメニティ、、御茶の水書房、pp. 213〜219、1991.2 2）金沢まちなか居住地再生研究会、「金沢市「まちなか小居住地再生にむけて提 言書小、pp. $29 \sim 42 、 2001.3$

3）金沢市都市政策部まちなみ対策課、「金沢市の都市景観施策小、2002

4)「金沢中心部居住地再生基䃈調查報告書小、株) 日本海コンサルタント、2000.10

5）田中勝、「豊田市の都心部における分譲マンションの需要構造と居住環境評 価一企業都市の都心部における人口空洞化問題の検郡、愛知県豊田市の場合一、 日本都市計画学会学術研究論文集、第 32 回、pp. $481 \sim 486 、 1997$

6）谷明彦、増田達男、「既成市街地における人口および土地利用の変化についてー金 沢市に捂けるケース・スタディーー小、日本建築学会大会学術講演梗概集、pp. 65〜66、 2000.9

7）川上光彦、高山純一、「戸建持家世帯の定住志向に関する調查研究一金沢市の 場合 -1、日本都市計画学会学術研究論文集、第 13 回、pp. $67 \sim 72 、 1978$ 8）川上光彦、高山純一、地域生活圈にお计る人口移動と地区特性に関する一考 察一金沢市におけるケーススタディーー」、日本都市計画学会学術研究論文集、第 13 回、pp. $67 \sim 72 、 1978$

9）秦秀宗、「農村地域における住民の定住意向に関する研究VII-群馬県芭楽町の 成人・中高校生を対象としてー1、日本建築学会大会学術講演梗概集、pp. 575〜 576、1999. 9

10）森川稔、「農山村青少年の居住環境評価と転出・㷌遙志向一嵫賀県朽木村を事 例としてー」、日本都市計画学会学術研究論文集、第 17 回、pp. $163 \sim 168 、 1982$ 11）天野克也、松本直司、「地方都市中心部における人口減少に関寸る研究小、日 本都市計画学会学術研究論文集、第 26 回、pp. $577 \sim 582 、 1991$

12）多治見左近、延藤安弘、门教地規模の定住・住みかえ意識に対する影響に関 する考察、日本都市計画学会学術研究論文集、第 17 回、pp. 253 258、1982 13）宫越淳一、松下裕、神原浩、羽根義、「室内空間の高さ感に対するファジィ 皘分モデルー（1）3属性での評価プロセスのモデル化一」、情報システム利用技術 シンポジウム、第17回、pp. 361〜 365、1994

14）位寄和久、両角光男、「ファジィ解析を用いた都市内空地の心理評価楎造の 分析一都市内空地の魅力度評価に関する研究一」、日本建築学会計画系論文集、第 467 号、pp. $105 \sim 112 、 1995.1$

15）高橋正樹、宮田紀元、「南関東地域都市部の集合住宅における居住者及ひ住 居属性からみた居住状況の類型化と類型別の居住嫱境に対する評価小、日本建築 学会計画系論文集、第 492 号、pp. 69〜74、1997.2

16）中島信之、武田英二、石井博昭、「社会科学の数理ーファジィ理論入阴」、裳 華房、1994

17) 日本ファジィ学会、「ファジィ湘度-講座ファジィ第3巻」、日刊工業新聞社、1993 18) 藤本勝成、「重回帰分析++」、日本建築学会大会学術講演梗概集 (近畿)、pp. 387 $\sim 388 、 1996.9$

19）高萩栄一郎、室伏俊明、「ファジィ測度の同定についてい、インテリジェント． システム・シンポジウム講演論文集、第 5 回、pp. $463 \sim 468 、 1995.9$

20) 久米弘、高梨一彦、実務的SPSSによる多変量解析法」、高文堂出版社、p. 140、1993 21）松下裕、「感性評価の数理モテルとその応用小、日本建築学会・情報システム 技術委員会情報システム利用技術シンポジウム、第 24 回、pp. 291 295、2001

(2002年 5 月 29 日原稿受理, 2003 年 3 月 12 日採用決定) 